Journal of Social Sciences (COES\&RJ-JSS)

ISSN (E): 2305-9249 ISSN (P): 2305-9494

Publisher: Centre of Excellence for Scientific \& Research Journalism, COES\&RJ LLC

Online Publication Date: $1^{\text {st }}$ October 2018

Online Issue: Volume 7, Number 4, October 2018

https://doi.org/10.25255/jss.2018.7.4.366.376

\title{
Problematic Issues in Translating Southern Bedouin Jordanian Arabic Idioms into English
}

\author{
Mr. Mheel AL-Smaihyeen \\ Faculty of Foreign Languages \\ English Language and Literature, University of Jordan \\ Faculty of Languages and Communication, Universiti Sultan Zainal Abidin \\ Gong Badak Campus, Terengganu, Malaysia \\ Email: Mheel.Alhwetat84@gmail.com \\ $\&$ \\ Dr. Ibrahem Bani Abdo \\ Assistant Professor, \\ Faculty of Foreign Languages, English Language and Literature, University of Jordan \\ Email: ibrahim_re@yahoo.com
}

\begin{abstract}
:
This study explores the problems facing English Language and Literature students at AlHussein Bin Talal University in translating Arabic language idioms used by Arabic Jordanian Bedouin speakers into English. This study is a qualitative research included 20 Jordanian senior level students of the English department at the University of Al- Hussein Bin Talal. A list of 14 Arabic Jordanian southern Bedouin idioms used in this study. The participants were asked to translate these 14 idioms. These 14 idioms were asked to be translated by the 20 participants. Then, their answers were collected and analyzed and categorized into different types of translations (lateral translation, meaning translation, irrelevant translation, no translation at all) according to (Alousque 2009; Basalamah 2010; Bani Abdo 2016; Alkhuli 2009; Abbasi 2012; Newmark 1981; Meryem 2009; AlShawi 2012; and Yowelly and Lataiwish 2000). The test was located at the University of Al- Hussein Bin Talal which is located at the southern part of Jordan.

The findings reveal that cultural differences between both languages (Arabic and English) consider as the main obstacles which face the English students' major when they translate Arabic Jordanian southern Bedouin idioms into English language. The appropriate pragmatic and semantic equivalents were also difficult to be found in the target language (English) by the 20 participants. Finally, the stylistics issues also are crucial in translating Jordanian idioms into English language.
\end{abstract}

Key words:

Translation, Arabic idioms, Pragmatics level, Semantics level, stylistics.

\section{Citation:}

AL-Smaihyeen, Mheel; Bani Abdo, Ibrahem (2018); Problematic Issues in Translating Southern Bedouin Jordanian Arabic Idioms into English; Journal of Social Sciences (COES\&RJ-JSS), Vol.7, No.4, pp:366-376; https://doi.org/10.25255/jss.2018.7.4.366.376.

This work is licensed under a Creative Commons Attribution 4.0 International License. 


\section{Introduction}

Language enables people to communicate with one another and enables them to express their needs, opinion, and knowledge .It is a system of communication that consists of a set of symbols used for speaking or writing. Language has both denotative and connotative meaning where the first one is the explicit or direct. Whereas, the connotative one refers to an implied meaning by a word apart from the thing which it describes explicitly. In addition, words carry cultural, emotional associations, and literal meanings or denotations. It denotes an essential meaning that cannot be noticed from individual words, for example, proverb simile (Alkhuli, 2009 ; Bajnaid et al., 2018).

Arabic language is different from English in many ways. Bani Abdo and Breen (2010) state that the word order in Arabic is completely different; Arabic is classified as a VSO (Verb Subject Object) language while English is VS order. In Arabic, it is possible to express a complete meaning in sentences that have no verb at all while in English you cannot since the verb is the main action of English sentences. Also, Arabic has a specific grammar, vocabulary, alphabet, phonology and specific culture that include religious, ideology, social geographical aspects where it's different from the English language. Arabic is from the Semitic language family whereas English language traces its original roots back to a Neolithic (late Stone Age) people known as the Indo-Europeans or Proto-Indo-Europeans; therefore, translation from Arabic into English language is not an easy and a problematic process because both languages belong to different language families and culture. Newmark (1981: 183-185) claims that the cultural value is important in translation and each language is partly considered as a reflection of a culture. Many translators like linguists tend to define culture as the customs of people and their ways of thinking.

Each Arabic speaking country or region also has its own variety of colloquial spoken and many dialects and its own culture. Al Sobh (2015) illustrates differences in cultures, varieties, religious believes, and dialects may create a challenge for the translators. AlSayadi (2016) points out many factors that may impact the dialect. The effects of foreign languages results in many linguistic novelties. The Arabic language usage is complicated because its division for literary language and dialects. Add, (MSA) is seen as the ubiquitous for all educated speakers. It is the version of high standard language, used in literary works, newspapers, TV broadcasts and educational institutions. The dialects form many colloquial variants of the Arabic language and each dialect has its own guidelines.

Translation must be closest natural equivalent message to the message of the source language and the translator should find the equivalent between the SL and the TL. What that means is that, in translation you could not be able to do more that getting close to the meaning of SL (Setyodwi, 2015). Whereas, Catford (1985) states that it is the means of communication borne out of contacts and interactions between the speakers of different languages and a kind of replacement of textual material in SL by equivalent textual material into the TL.

Translation reduces the gap between people who have different languages and it facilitates contact between people who speak different language. Linguists believe that the function of any language is that of communication, and expressing one's self. 
However, people sometimes need to communicate not just within their language, but within their local speech communities. Basalamah (2010) states that " translation results from an understanding of a source text (the original) from its reading, and thus from its interpretation". Translation is not transferring words from one language to another, translators must understand source text before translating it into the target text, but sometimes language users cannot understand each other because of belief, local customs, religious, etc.

Translating standard text to another standard text could be easier from translating idioms used by local people because the translator is unconscious about these varieties and lack of familiarity of factors that are related to regional dialects which affect words' meaning. Therefore, the current study casts the light on main problems that encounter B.A English language and Literature Students at Al- Hussein Bin Talal University in translating Arabic language idioms used by the Jordanian-Arabic speakers in the Bedouin regions into English. In Bedouin regions, there are many different dialects and they are considered the largest areas in Jordan in terms of distance. They situated in south of Amman around $200 \mathrm{~km}$, and they include several cities, towns, and villages. People in South Bedouin Regions speak variant accents different from many Jordanian dialects and they tend to speak a variety of local idioms and expressions that have specific connotations cannot be understood by other people in Jordan. People in South Badia use several proverbs, religious, and social idioms and expressions. It can be said that translating some kinds of their expression, idioms, and proverbs is not an easy task, and it could cause certain problems for translators due to they are not aware about Bedouin accents and their local expressions and idioms. Difficulties in translating some Bedouin expressions, proverbs, and idioms are due to differences in cultures, each culture has its own idioms, proverbs and expressions; they could refer to meaning that has no equivalence between source language and target language. Only in some cases can be found equivalence between the source language and the target language for the expression, and the idiom, but they used in different situations. Translating idioms, expressions, and proverbs lean on totally on the context in which they have existed (Balfaqeeh, 2009). Thus, translators should understand the cultural context without taking the literal meaning.

\section{Literature Review}

A plethora of studies have been conducted in order to investigate translation as an important aspect of conveying meaning from one language to another. Idioms are treated as one class of figurative expressions which occur in all expression of "at least two words which cannot be understood literally and which function as a unit semantically". Generally, translation is a difficult task, and translating idioms in particular, makes it rather a more difficult task. Pedersena and Trosborg (1997:109) argue that: "The translation of idioms is as difficult as it is central". Larson argues that: "the translator must first be sure of the meaning of the idiom and then look for the natural equivalent way to express the meaning of the idioms as a whole".

Meryem (2009) examines twenty one students majoring in applied linguistics at the English Department in Mentouri University of Constantine, the test taken randomly from 
all students of first year Master as a great attempt to investigate main problems of translating idioms and proverbs. The findings of the research showed that cultural differences cause problems in translation from Arabic to English language. Al-Shawi (2012) argues that the process of translating from a particular language to another is a real challenge due to the distinction between the $S L$ and the $T L$, also the differences in their cultures. As shown previously, difficulties of translation include several things such as stylistic and the linguistic characteristics, also the cultural and social differences between SL and TL. Translation of religious idioms and some social backgrounds are the main obstacles that encounter translators.

Certainly, the culture has an influence on the process of translation in regarding the degree of combining of the source text (ST) in the target culture (TC) could be different, and could lead to many difficulties for the translator. In this respect, culture may lead to different types of translation. Translation may, sometimes, result in a "shift towards the target culture, and the translated text may or may not merge completely in the target culture" (Yowelly and Lataiwish, 2000:107). Bani Abdo (2016) also states that style is considered an essential part in translation. Style is considered as combination of different aspect of a language such as culture, costumes, heritage, semantic, pragmatic, ect.

Alousque (2009) figures out cultural words which require a cultural background to be correctly recognized and thus indicating translation problems. The problems that face translators are cultural problems results because the cultural differences and their ignorance of the culture of the target language and dialects. In other words, problems main reasons are a number of linguistic phenomena, such as the different meaning range of the cultural words in the source and the target languages, the absence of the cultural concept in the target language, the loss of meaning and the metaphorical meaning conveyed by many cultural words. The study indicated the some constraints of the translation procedures and strategies used to transfer the original meaning into the target language (loan, functional equivalence, descriptive equivalence, approximate equivalence) and the differences in the conceptualization of reality as reflected by the translation of metaphorical words and expressions from the French domain of cooking. These differences point to a cultural gap which makes the translation of cultural lexis a hard task. Finally, the researcher of the current study felt that there is a great need to conduct these kinds of study.

\section{Statement of the Problem}

The cultural differences and linguistic differences are considered to be the most problematic issues of translation. Translators must be aware of the SL culture in order to understand the meaning of a specific expression of the SL. Jordanian translators face several cultural problems in translation between English to Arabic (Dweik and Suleiman, 2013). Translating local idioms associated with particular society that are cultural connotations which has special ecology, religious, social habit, concepts and belief. Consequently, this study is investigating the problems facing senior English students at Al- Hussein Bin Talal University in translating Arabic Language idioms used by speakers of Jordanian Arabic in South Bedouin areas into English Language. 


\section{Research Objectives}

This study is devoted to achieve the following research objectives:

i. To explore the main difficulties in translating the Southern Bedouin local idioms dialect.

ii. To provide short analysis for the reasons behind the difficulties of translating locally loaded idioms in South Bedouin.

\section{Research Questions}

This study investigates the following questions:

i. What are the problems in translating the Jordanian Southern Bedouin dialect idioms?

ii. What are the causes behind the problems of translating the Jordanian Southern Bedouin dialect idioms?

\section{Method of the Study}

This study is a qualitative and descriptive analysis researching in translating Southern Jordanian Arabic (SL) idiom into English (TL). The sample of the study was randomly chosen including males and females. It involves a total of 20 senior students of English language and literature department at Al- Hussein Bin Talal University of the academic year of 2016-2017. To collect data, a test was designed to find out the difficulties that EFL senior students may face in translating specific Jordanian southern idioms. This test has two goals where to make sure that the sample of the study makes mistakes in translating these idioms and to determine the reasons behind these mistakes that are based on analyzing the answers of the students. The students were requested to translate 14 idioms of the local Jordanian Southern Bedouin dialect and to mention the reasons behind not being able to translate the idioms' expression. Then, the test's results were analyzed to find out the reasons behind these translating problems. The test were also analysed by using SPSS program and a textual analysis was made to discuss the factors that may affect them.

\section{Discussion and Findings}

This section analyse of the elicited data. The analysis of the data views the participants' performance in translating these idioms used by Jordanian Arabic Southern Bedouin Area. Different criteria were used as the followings based on (Alousque 2009; Basalamah 2010; Bani Abdo 2016; Alkhuli 2009; Abbasi 2012; Newmark 1981; Meryem 2009; AlShawi 2012; and Yowelly and Lataiwish 2000):

i) literal translation which relates to conveying the meaning of the idiom from the source language into the target language in terms of word-for-word translation without referring to the sense of idiom in the source language.

ii) Meaning translation which associates with paraphrasing the essential meaning of an idiom into the target language.

iii) No translation at all where there is equivalence.

iv) Irrelevant translation which contains unrelated translation to the provided idiom. The following figure displays the frequencies and percentages of translated idioms based on the previous four criteria. 


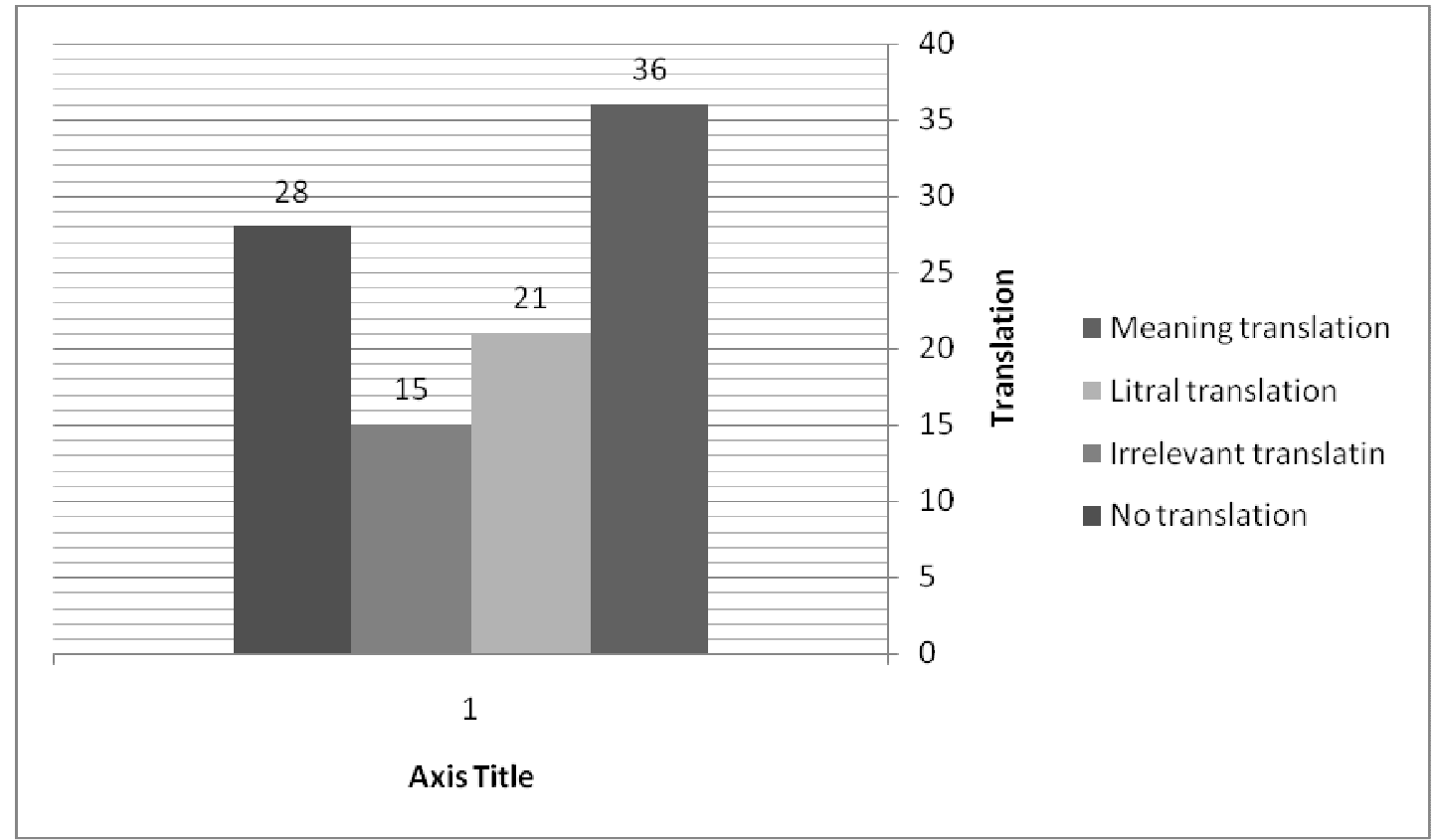

Figure 1: The Performance of the Translators in Translating Local Idioms from Jordanian Arabic as a SL into English as a TL.

As figure (1) above shows, the participants were provided with a number of local Arabic idioms used by speakers of Jordanian Arabic in South Bedouin Areas. Figure (1) shows that $15 \%$ of the participants presented translation to the idioms irrelevantly, $21 \%$ presented translation literally, 36\% applied meaning translations and $28 \%$ did not present any translation for the chosen idioms as a general conclusion for the overall translation of the idioms from Arabic Language into English Language. The next section shows a discussion on the translation of the idioms separately shown in frequencies and percentages for the translation of each idiom in English language as discussed below:

Idiom 1: "سارحه والرب راعيها"

- As the participants provided, this idiom was not translated as a literal. That is, when participants have been asked about the reason, most have stated that there is no equivalent for this idiom in English language' and the 'the meaning of an idiom cannot be understood from the meaning of its individual words'.

- 6 participants $(30 \%)$ have paraphrased the meaning of this idiom in the TL where they provided different translations such as 'no one to control his behavior'; 'no one punish him'; and 'he does what he want'.

- 8 participants $(40 \%)$ have not provided translation for this idiom. This percentage is considered a high percentage compared to other strategies of translation as a result of the linguistic and cultural differences between Arabic and English language.

- 6 participants (30\%) have used unrelated translation by replacing the idiom with different expressions such as 'never stand up never sat down' and 'when the cat is away 
the mice play'. This percentage indicates that participants are unaware of the meaning of this idiom; therefore, they have used nonequivalent translation in the TL.

Idiom 2: "لأسوّد لياليه"

- This idiom indicates 'threat and revenge from someone'. It was translated literally by 9 participants (45\%) as 'I will make his nights dark' which is not a proper translation as the meaning extracted from the literal meaning of each word separately. This may indicates that the translators may not be acquainted with appropriate equivalence used in the TL.

- 6 participants (30\%) have followed the paraphrasing strategy of the meaning as a "threat" where it has been translated as 'I will punish him strongly'.

- 3 participants (15\%) didn't translate the idiom at all as it is related to their lack of knowledge of the meaning of this idiom or the difficulties of finding the appropriate equivalent in the TL.

- Finally, two participants (5\%) have provided an unrelated translation.

Idiom 3: "المصاري وسخ ايدين"

- This idiom means that 'money is not important, but what is important is dignity, and it expresses satisfaction of what you have'.

- This idiom was translated literally by 6 participants (30\%) as 'money is hands' dirty'. This kind of translation does not serve the purpose of the translation which involves transferring the meaning of the idiom rather than translating the linguistic structure.

- 4 participants (20\%) have provided a semantic translation such as 'money you can get easily'; 'money is not important'.

- 8 participants (40\%) didn't translate the idiom.

- Finally, 2 participants (10\%) have provided irrelevant translation such as 'keep yourself'; 'pay money to buy good things'. Idiom 4: "يذوب الثلج ويبان الي تحته"

- This idiom is used when 'the new news is spread out and people are not certain if it is correct or not'.

- This idiom has been translated literally by 13 participants (65\%) as 'snow will melt and what under it will be clear'.

- 6 participants (30\%) have paraphrased the meaning of this idiom as 'time shows us what happened'; 'time tries'.

- On the other hand, a participant (5\%) did not translate this idiom.

- None of the participants have provided unrelated translation. Idiom 5: "الي في القدر تطوله المغر افه"

- This idiom is used in a situation where "whatever a man sows, that he will also reap'.

- Only 3 of the participants (15\%) have translated this idiom literally as 'what in a pot, you can get it'.

- Other 5 participants (25\%) have conveyed the meaning of this idiom as if you did good deed you would get good results'.

- 9 participants (45\%) have failed to provide an appropriate equivalence in the TL. This indicates a lack use of the translation strategies.

- 3 participants (15\%) have provided unrelated translation as 'Where there is a well, there is a way'.

Idiom 6: "وجهه يقطع الخميره من السوق"

- This idiom expresses 'abhorring from someone or something'. 
- This metaphorical expression was translated literally by 8 participants (40\%) as 'because his face, yeast will finish from market'.

- 10 participants (50\%) have paraphrased the meaning as 'he is a bad omen' and 'hopeless'.

- Only a participant (5\%) did not translate the idiom.

- Unrelated translation as 'tit for tat' was also provided by a participant (5\%). Idiom 7: "لا حر ام يطيح ولا عيل يصيح"

- This Bedouin idiom expresses 'that someone has nothing to do of his/her life'.

- This metaphorical expression literally translated by 3 participants (15\%) as 'no blanket falls and no baby cries'.

- 8 participants (40\%) have paraphrased the meaning in English as 'someone has no responsibilities'; 'no wife no children'.

- 2 participants (10\%) have failed to present any translation.

- Finally, 7 participants (35\%) have presented unrelated translation such as 'children are blessed'; 'no time for sleeping'; and 'no time for love'.

Idiom 8: "اعتبرني عصاك الي ما تعصاك"

- This idiom expresses 'obeying in everything' and expresses 'supporting close friend in all cases'.

- $40 \%$ of the participants (8) have literally translated the idiom as 'consider me as your stick that never disobeys you'.

- $\quad 30 \%$ of the participants (6) have paraphrased meaning as 'I will help you'; 'I will be with you'; and 'Don't afraid'.

- $20 \%$ (4 participants) have failed to provide any translation.

- $10 \%$ (2 participants) have unrelated translation such as 'a piece of cake'; and 'it is difficult for you'.

Idiom 9: "سبع و لا ضبع"

- This idiom indicates two animals 'panthera leo and hyena' where both have an indication in Arabic culture. The first one stands for 'goodness' while the other stands for 'badness'. This proverb is used in Arabic culture to indicate fertility.

- Literal translation is $0 \%$.

- $50 \%$ of the participants (10) have presented the meaning as 'good or bad'; 'got it or not'; and 'right or wrong'.

- $45 \%$ of the students (9) have failed to provide any translation, which may refer to inability of interpreting the idiom.

- A participant presented an unrelated translation as 'What's up?'. Idiom 10: "البر اطيل ترخي السر اويل"

- This term is used in a situation where 'someone gives everything to get money or bribe'.

- None of the students translated it literally.

- $30 \%$ of the participants (6) have provided a semantic equivalent such as 'a spoiler does everything for the sake of money'; and 'a bribe makes every things easy'.

- $40 \%$ (8) participants did not present any translation as a result that they do not know the semantic equivalent in the TL.

- $\quad 30 \%$ (6) participants have represented unrelated translation as 'money speaks'; 'money is good'; and 'corruption is not allowed'.

Idiom 11: "تبدلت غز لانها بقرود" 
- This idiom is used when speakers express 'unhopeful case with sarcasm'.

- $20 \%$ (4 participants) have presented literal translation as in 'Gazelles changed into monkeys'.

- $60 \%$ (12 participants) have translated the idiom semantically as in 'changing situation from good to bad'.

- $15 \%$ (3 participants) have not represented any translation; while $5 \%$ of them have provided unrelated translation as 'Gazelles are good'.

Idiom12: "إبعا في ايدك ماهي زي بعضها "

- This idiom denotes 'people are different in everything such as morals, behaviors, way of talking....and so on'.

- Literally translated by 1 participant as 'your fingers on your hand are different'.

- $65 \%, 13$ participants have used metaphorical expressions or meaning translation strategy to express 'people are different even relatives'; 'brothers are different'; and 'people are not equal'.

- $20 \%$ of participants did not present any translation.

- $15 \%$ (3 participants) present unrelated translation as 'people have different ideas'; and 'people have different size'.

Idiom13: "اذا سمعت المديح ارتع من دونه"

- This idiom expresses: 'if you hear someone praises something, you should not belief him/ her quickly because this praise could be used as propaganda'.

- Literal translation was none.

- $3(15 \%)$ participants have a meaning translation technique such as 'Don't believe anyone'; and 'Be aware of trick'.

- $14(70 \%)$ participants have failed to provide any translation, as a result of inability to interpret the idiom or to the appropriate meaningful equivalent in the TL.

- $3(15 \%)$ of participants have provided unrelated translation such as 'good things bring luck'; 'not all things are fake'; and 'where there is a well, there is away'.

Idiom 14: "من طين بلادك حط على خدادك" '

- This idiom represents a marriage advice that means 'it is better for you to marry your relative'. This metaphorical expression used 'when someone hesitates in choosing wife'.

- It is literally translated by $4(20 \%)$ participants such as 'from clay of your country put in your cheeks'.

- 7 (35\%) participants have paraphrased the meaning in the TL AS 'better to marry from your relatives'; 'the one you know is better that you don't know'.

- $3(15 \%)$ participants have failed to present any translation; whereas, $6(30 \%)$ of the participants have provided unrelated translation as in 'east or west, home is the best'; 'Jordan first'; and 'I like my country'.

\section{Conclusion}

The current study concluded that, there are many factors that may consider problematic in translating a local Arabic idioms used by speakers of southern area of Jordan into English.

As examined, it can be said that there are several reasons lie after these problematic issues in translating these idiom mentioned in section (7) as follows: 
I. Translators did not pay attention to the pragmatic level. As Pedersena and Trosborg (1997:109) argues that: "The translation of idioms is as difficult as it is central". Larson argues that: "the translator must first be sure of the meaning of the idiom and then look for the natural equivalent way to express the meaning of the idioms as a whole".

II. Translators were not aware of the different equivalence strategies used in translation to convey the appropriate meaning of these idioms. Alousque (2009) states the translators must get familiar with the different strategies of translation as 'loan', 'functional equivalence', 'descriptive equivalence', 'approximate equivalence'.

III. Few translators were not able to translate the idioms since they were not able to understand the source text. As Basalamah (2010) stated "translation results from an understanding of a source text (the original) from its reading, and thus from its interpretation". Translation is not transferring words from one language to another, translators must understand source text before translating it into the target text, but sometimes language users cannot understand each other because of belief, local customs, religious, etc.

IV. Translators had a stylistics problem in translating these idioms. As Bani Abdo (2016) mentions that style is an essential part in translating from the ST (Arabic) into the TL (English) or vise a versa.

V. Translators tended to use different translation strategies such as a paraphrased meaning or a literal translation that cause the misinterpretations occasionally. Alkhuli (2009) words carry cultural, emotional associations, and literal meanings or denotations. It denotes an essential meaning that cannot be noticed from individual words.

Translators must be aware of culture source and target languages (Abbasi 2012; Newmark 1981; Meryem 2009; Al-Shawi 2012; and Yowelly and Lataiwish, 2000) as a result translators would not be able to translate these idioms if they are not aware of the cultural aspect of the source text.

The findings reveal that cultural differences between Arabic (SL) and English (TL) consider as the main obstacles which face the English students' major when they translate Arabic Jordanian southern Bedouin idioms into English language. The appropriate pragmatic and semantic equivalents were also difficult to be found in the target language (English). Finally, the stylistics issues also are crucial in translating Jordanian Idioms into English language.

\section{References}

Abbasi, G (2012) Islamic Azad University Urmia Branch/Iran.

Alousque, I. (2009). Cultural domains: Translation problems. Revista de Linguistica y Lenguas Aplicadas, 4, 137-145.

Al-Sayadi, M. (2016). Kazimierzwielki. University of Bydgoszcz.

Al-Shawi, M.A and Mahadi, T.S. (2012). Strategies for translating idioms from Arabic into English and vice versa. Journal of American Arabic Academy for Sciences and Technology, 3 (6). Volume 3, Number 6. 
Bajnaid, A., Veltri, G., and Elyas, T. (2018). Utilizing Matrimonial Web sites Among Saudi Users: An Empirical Study. Digest of Middle East studies, 1-30.

Balfaqeeh, N. (2009). Strategies for translating idioms and culturally Bound expressions within the human development genre, (Unpublished master thesis), University of Birmingham, Birmingham: United Kingdom.

Bani Abdo, I (2016). Stylistic Issues of Literary Translation: English and Arabic. Noor Publishing. Germany.

Bani Abdo, I., \& Breen, G. (2010). Teaching EFL to Jordanian Students: New Strategies for Enhancing English Acquisition in a Distinct Middle Eastern Student Population. Creative Education, 1, 1, 39-50.

Basalamah, S. (2010). Translational Critique of the Arab Postcolonial Condition. In S. M. Shiyab, M. Gaddis Rose, J. House, \& J. Duval (Eds.), Globalization and the Aspects of Translation (pp. 68-77). Cambridge Scholars Publishing.

Catford, J.C. (1985). A linguistic Theory of Translation, Oxford University Press.

Dweik, B. and Suleiman, M. (2013). Problems encountered in translating cultural expressions from Arabic into English. International Journal of English Linguistics, Vol 3., Num 5.

Meryem, M. (2009). Problems of idioms in translation case study: First year master. Mentouri University- Constantine.

Newmark, P. (1981). Approaches to Translation. Oxford: Pergamon Press.

Pedersen, V.H. (1997). "Description and Criticism: Some Approaches to the English Translations of Hans Christian Andersen", in A. Trosborg(ed.) Text Typology And Translation. Amsterdam/ Philadelphia: John Benjamins Publishing Company. (pp.99-113).

Setyodwi. D. R. (2015). Technique analysis on Surah Al-Lail of English translation, English Education Department, Tarbiy, Faculty state, islamic college of Ponorgo.

Yowell Y. A; Muftah S Lataiwish. (2000). Arabic language translating into English. University of Garyounis, Dept. of English, Benghazi, Libya. 